\title{
Today Problems and Cases of Territory Promotion: Yakutia and Kazakhstan
}

\author{
Svetlana Yurievna Zalutskaya ${ }^{1}$, Lena Nikolaevna Pavlova ${ }^{1} \&$ Oksana Mikhailovna Salnikova ${ }^{1}$ \\ ${ }^{1}$ Philological faculty, North-Eastern Federal University (NEFU), Russian Federation \\ Correspondence: Svetlana Yurievna Zalutskaya, Kulakovsky st. 42, Yakutsk, 677000, Russian Federation.
}

Received: February 28, 2015 Accepted: March 20, 2015 Online Published: April 24, 2015

doi:10.5539/res.v7n6p217 URL: http://dx.doi.org/10.5539/res.v7n6p217

\begin{abstract}
Specific features of development of Yakuia's and Kazakhstan's brands have been analyzed. Comparative analysis of normative documents specifying image making policy of largest subject of Far Eastern Federal District of Russian Federation and Republic of Kazakhstan has shown efficiency level of undertaken measures. Inadequate level of social and economic development and, consequently, tendency to differentiate internal and external image is one of the problem of the republics' branding policy. The level of social provisioning of population defines image of the republics. Kazakhstan is the most successful among post-Soviet countries in realizing image policy. Social and economic development program of the Republic of Kazakhstan allows bringing closer internal and external image. But image of former Soviet republic as interpreted by global community is questionable. The Republic of Sakha (Yakutia) is not only the biggest but perspective for economic development region of Russia. But the problem of its investment potential for international partners is still pressing. Yakutia's image is developing in situation of underdeveloped tourism infrastructure and other infrastructure with typical for all Russia social and economic problems and extreme climate conditions. Yakutia's development strategy is aimed on overcoming these obstacles and using natural and climate resources for comfort living. Successful cases of territories with similar social and political situation allow correcting existing image development programs and develop new strategic plans of development of the region.
\end{abstract}

Keywords: region, branding, Public Relations, PR professional, requirements, conditions, case, Kazakhstan, Yakutia, problems, analysis

\section{Introduction}

At the turn of the new millennium Public Relations (PR) and advertising have covered information space of Yakutia that is the biggest subject of Russian Federation and became integral part of everyday life of Yakutia community. It is impossible to think of today community without PR and it took its place in communication sphere of the republic. It appeared to be sensitive to professionals in this area of this relatively new for Russia. The system of PR communications of Yakutia needed specialists who

- Spoke three languages that define specific of the market and forms lingual environment of all the territory of the republic. These languages are Russian, Yakut language and one of European languages. Yakutia is multinational republic with representatives of almost 120 nationalities living in. Russian and Yakut are titular ethnic groups. Specifics of geographical position allows the republic to actively develop social and economic relations with subjects of Asia-Pacific Region and other countries interested in investments to Yacutia economy and having tight relations in cultural, scientific, educational spheres and sports;

- Know the basics of cultures of peoples that are active participants of PR market of the republic. Culture is an influence dominant for personality's mentality for PR manager. Personality is understood as an "aggregate of views, ideas and state of mind that are realized in traditions, customs and rituals typical for a certain social, national and ethnic or territorial community the reflect specifics of mental make-up and the way of thinking of its members" (Vishnykova, 1999, p. 398);

- Understand and professionally withstand different cases of nationalism, chauvinism and political extremism that have negative impact on foreign relations, social accord of people living in the republic and people migrating over its territory due to active social and economic transformation of the Rebublic of Sakha (Yakutia); 
- Responsible for their activity in information and communication area on the base of awareness of mechanisms of forming and development of information and communications in the situation of the Rebublic of Sakha (Yakutia) as legally competent subject of Russian and global information space;

-Pay special attention to solving problems of social Public Relations as the most important factor of stabilizing of conflict producing situation in points of social tension of the region and development of adaptive forms of behaviour of different social strata in the situation of scale reformation of the region.

High qualified professionals are being actively trained now in the Republic of Sakha (Yakutia) that is ready to face the challenges of today reality.

\section{Method}

Yakutia's image is one of pressing problems and one of trends of social communications of the republic PR specialist works with. PR specialist is responsible for promotion of the region as one of leading subjects of the Far Eastern Districts of Russian Federation. Professional society headed by the Chairman of the Council of Yakutia representatives of Russian PR Association L. N. Tsoi plays special role in this process. It is engaged with coordination of work over the concept of image policy of the republic. This document is necessary as it is formulated by the Council because "territorial branding is not only marketing approach to the problem of regional development but as strategically important direction of communication policy of countries, cities and provinces. In the new millennium it became necessary critically important tool that defines the main direction of development of a region for medium-term and long-term perspective" (Social dimensions of image policy of the region, 2011, pp. 7-8). Professionals explain the boost of importance of branding by constant threat in condition of global economic recession with sharping competition for investments. Attraction of the new sources became more difficult and requires more and more attention of the bodies that define survival strategy of this or that community.

Existing realities place the task for subjects of RF to deliver to market something unique, original, different from the others, something that attract attention of clients and allows controlling social and economic relations more efficiently, something that support "prosperity of civil society... and promoting the growth of attachment for a place people live, work and rest in" (Dinnie, 2013, p. 28); something that has a perspective of leading in this or that direction of future development of the country as a whole. This commitment of a region to support its unique position and positive image in external and internal markets is critically important element of communicative management as well as strategic marketing that includes the complex of proposals and advantages that correspond to expectations of target audience, reflect specifics of the territory, level of its development and the level of its attractiveness.

Terms "image" and "brand" in today theory of PR are applied to objects of different areas of living activity of a man and consequently "it is possible to brand not only goods but everything!" (Tchumikov \& Bocharov, 2008, p. 181) including territories from small settlement or megalopolis to state or unions of states. Keith Dinnie was the first to use the concept of branding of territories" (Dinnie, 2013). In European practice the term "geobranding" is also widely used (Lebedeva et al., 2014). Popular terms of Russian researches are countrybranding or national branding, defined by S. Ankholt as "strategic approach to development of competitive advantage and the vision of direction a country may move in. A country cannot compete without such a vision" (Ankholt, 2004, c. 92). National brand strategy defined by Ankholt is based in six elements: promotion of tourism, brands export, population, government, culture, history and tradition, investments and immigration. Later the strategy was enriched by the others not less important elements: the role of movie theatre, fashion industry or social organizations, national diaspora as instruments of brand communication.

Russian researchers consider image communications and such concepts as state policy, national awareness, foreign policy, media and PR-technologies as the factors that have the greatest impact on brand forming. The role of brands of goods in forming image of the country is also growing. It is because "with the help of brands of goods customers form their opinion of national identity of this or that country", wrote A. M. Chernysheva and T. N. Yakubova in branding handbook for bachelors (Chernysheva \& Yakubova, 2014, pp. 38-39). Breaking with extractive business model, support for commercial and social initiatives of citizens, better conditions for competence for domestic goods with popular global brands - these are conditions of broadening of possibilities for development of national brands and promotion of Russian territories.

Development of influential brand of the country, forming positive image is becoming more important because it is necessary to "provide comfortable environment for living, improvement of the quality of living, development of effective system of municipal management" (Bogachev, 2010, p. 91). The main aim of development of territorial brand is growth of people's welfare. "Persuading the aim of development of a brand that impresses 
tourists and external visitors it is easy to forget about the needs of native people. Although these are people who play important role as loyal supporter and messenger of brand" (Dinnie, 2013, p. 22).

To achieve plural effect of territorial branding professional activity of social communications specialists is required. The farer is the territory from administrative cent the more active it should be in solving PR tasks that have several complications:

1) The process of branding positioning should assure provisioning the main set of services and support operating state of infrastructure to satisfy requirements of citizens, business and visitors;

2) Place may require new factors of attraction to continue receiving support of existing business and state and to draw new investments, companies and people;

3) It is necessary for a place to communicate all its specifics and advantages by means of aggressive image and communication program;

4) Place should get support of native people, leaders and influential institutions to draw new companies, investors and visitors with hospitality and enthusiasm (Kotler et al., 2005, p. 212).

As we can see the process of forming and maintaining viable territorial brand presupposes systematic and multifaceted activity. But in practice the processes of branding positioning and image making for a places in particular regions of Russian Federation are hampered by a number of reasons:

1) Absence of relevant targeted programs that comply with all today requirements;

2) Absence of competent territorial branding management bodies;

3) Absence of integrity of image of a region;

4) Absence for interests of only one group of participants of this process;

5) Absence of organization of partnership of all social communities;

6) Absence of territorial branding professionals and other.

Violation of communicative principle at the stage of working out strategic projects (concepts) of development of a territory is the most severe drawback of branding of a subject of RF as an integral part of a single whole (Chumikov \& Bocharov, 2008; Samover, 2009; Image policy of RF, 2012 and others). It leads to disintegration of participants and people interested in promotion of a region especially population and business entities. All social groups should understand the necessity of cooperative development of perspectives of territorial development and join and develop bodies to realize perspectives and mobilize local and external resources.

\section{Results}

Let us analyze some of possibilities of branding positioning of the region of RF. We have studied image potential of the Republic of Sakha (Yakutia) (The Conception of Image Policy of RS (Ya) for 2012-2020, 2011) in the context of existing experience of the Republic of Kazakhstan as one of the leaders among the post-Soviet countries (on the base of media materials, and Pavlova, 2012, 2013; Image policy of RF, 2012).

Content-analysis of Kazakhstan's media allows making conclusion that Kazakhstan's specialists of territorial images and brands as well as politics and PR experts apply professional approach to image making. Basing on uniform PR technologies they account for specifics of territory, national culture, the set of specific cultural values of the Republic of Kazakhstan for successful promotion and communication of necessary meanings to possible consumers of image products.

In a quarter of a century Kazakhstan has significantly advance in global arena. It is one of the most economically stable states of all post-Soviet and Euro-Asia space and demonstrate readiness to play important role in global policy. It may be proved by the "Strategy of Kazakhstan Entering the List of $50^{\text {th }}$ Most Competitive World Countries" (Address of the President of the Republic of Kazakhstan N. Nazarbayev to People of Kazakhstan for 2006; Address of the President of the Republic of Kazakhstan N. Nazarbayev to People of Kazakhstan for 2012; The Conception of Foreign Policy of the Republic of Kazakhstan for 2014-2020, 2014). The most meaningful PR project of Kazakhstan was moving the capital to the new city (Astana as the New Wonder of the World, 2014). Invitation of famous Japan architect Kisho Kurokawa as developer architectural concept of the city was the feature of event marketing. British architect Norman Foster who design the unique The Palace of World supported the mightiness of the project. Planning and building of the city of Astana provided information ground for numerous information agencies. Hosting important international events and summits, organization of cultural events, VII Winter Asia Games "Asian Olympic Games-2011" and other events have also attracted attention of global community to Kazakhstan. Progress of Kazakhstan people in development of sports, economy, culture 
draw genuine interest and respect of leaders of partner countries. Experience of Kazakhstan's branding specialists became research object of scientific community of European and Asia countries including Russia.

Comparative characteristic of branding potential of the Republic of Sakha (Yakutia) and the Republic of Kazakhstan is provided in Table 1.

Table 1.Comparative characteristic of branding potential of the Republic of Sakha (Yakutia) and the Republic of Kazakhstan

\begin{tabular}{|c|c|c|}
\hline Criterium & Kazakhstan & The Republic of Sakha (Yakutia) \\
\hline \multirow[t]{4}{*}{$\begin{array}{l}\text { Availability of } \\
\text { integral development } \\
\text { strategy of a region }\end{array}$} & $\begin{array}{l}\text { 1. To the State Program of Social and } \\
\text { Economic Development of the City of } \\
\text { Astana for 2006-2010. }\end{array}$ & $\begin{array}{l}\text { 1. The Republic of Sakha } \\
\text { (Yakutia) image policy concept for } \\
\text { 2012-2020. }\end{array}$ \\
\hline & $\begin{array}{l}\text { 2. Address of the President of the Republic } \\
\text { of Kazakhstan N. Nazarbayev to People of } \\
\text { Kazakhstan } \\
\text { "Kazakhstan-2050"- - new political course of }\end{array}$ & $\begin{array}{l}\text { 2. The scheme of complex } \\
\text { development of productive force, } \\
\text { transport and power industry up to } \\
2020 \text {. }\end{array}$ \\
\hline & $\begin{array}{l}\text { matured state" (2011). } \\
\text { 3. Conception of Foreign Policy of the } \\
\text { Republic of Kazakhstan for 2014-2020 } \\
\text { (2014). }\end{array}$ & $\begin{array}{l}\text { 3. "Scheme } 2025 \text { " is under } \\
\text { development together with main } \\
\text { directions of development up to } \\
\text { 2030. }\end{array}$ \\
\hline & $\begin{array}{l}\text { 4. Information and image program of } \\
\text { Kazakhstan consist of several } \\
\text { industry-specific programs: } \\
\text { Plan information and image making work }\end{array}$ & $\begin{array}{l}\text { 4. Industry-specific } \\
\text { development projects of regional } \\
\text { development. But these have no } \\
\text { image component. }\end{array}$ \\
\hline
\end{tabular}
about realization of program article of President N. A. Nazarbaev "Social modernization of Kazakhstan: Twenty Steps to Society of Universal Work" (for 2012).

- Conception of image policy of the bodies of fiscal policy of the Republic of Kazakhstan (2012).

- Order of the Attorney General of the Republic of Kazakhstan "To Image Policy of the Office of Public Prosecutor and the Order of Cooperation with Media".

- Agenda of realization of the State Program of Further Modernization of law-enforcement authorities of the Republic of Kazakhstan for 2014-2020 (2014).

- Tourism development conception up to 2020 is under development.

Aim of territorial Development of favourable image of the branding Republic that supports solving strategic tasks on regional and international levels in political, social and cultural areas, purposeful management of information and communicative resources under management of executive bodies of state authorities.

Factors of territorial Stability, high level of economical attractiveness development, cultural integrity and individuality of sovereign state in perception of international community:

Development of stable image of the Republic of Sakha (Yakutia) as dynamically developing perspective and comfort for living and business region.

1. Kazakhstan was the chairman state of

Objective strategic advantages of the republic (basing on materials of scientific and practical articles):

1. Unique experience of practical economy and living activity 
Organization for Security and Co-operation in Europe (OSCE) (2010).

2. Kazakhstan was the head of the Organization of the Islamic Conference (OIC) as well as SCO in anniversary year (2011).

3. VII Asia Olympic Games (Kazakhstan as a center of international sport and tourism).

Kazakhstan has a number of geographical advantages due to location in the center of Europe and significant transit potential as well as diversity of climate and nature zones together of communication infrastructure. Territorial and geographical factor is successfully used in forming of the brand of the country.

Availability infrastructure

of Program of forming and development of national innovative system was approves in Kazakhstan in 2005. Four following elements of innovative system were built in the country: science, innovative infrastructure, infrastructure for funding innovations and companies deploying innovations.

Image advertizing 1. Main investment project "Green Block subject

\section{EXPO Village", Astana.}

2. International

exhibition

"EXPO-2017". Topic: "The Energy of the Futire".

3. Industrialization of Kazakhstan.

4. Social and cultural development of the Republic of Kazakhstan.

5. Industry-specific projects as well as wide scale initiatives in tourism, sport, and investments; unique touristic objects; scientific and educational projects, etc. provisioning in situation of circumpolar territories.

2. Successfully economically developing region, leader of the Far Eastern District by such indicators as the volume of industrial production, culture, housing construction and the level of income per capita.

1. Birth rate growth is a special indicator. The doctrine of healthy life style is being realized.

2. Harmony of nations and religions is the base of social and political stability in the republic.

3. The policy of Federal Center and personal attention of the President of $\mathrm{RF}$ to the republic strengthen its importance as a subject of Federation with significant development potential.

4. Developing center of science, culture and tourism.

5. Nature of Yakutia is an integral part of nature complex of the Earth, unique property of a mankind, biospheric reserve of the planet. The vastest territories have not been impacted by economic activity of a man. International authority of the republic in environmental protection is relatively high.

Understanding of strategic importance of the problem; working out necessary projects ("Scheme 2020" at first) and infrastructure development program. But it should be mentioned that progress and the quality of relevant works controlled b provincial government are low.

Investment projects in the scope of "Scheme 2020 (in perspective 2030)" and "Power of Siberia"; and the experience of economic activity on circumpolar territories; ALROSA; diamonds; jewellery; touristic project "The Pole of Cold"; natural park "Lenskie Stolby" (the object under protection of UNESCO); people epos olonkho (the object under protection of UNESCO); archeological finds including mammoth; scientific advances of scientists of Yakutia; International Sporting Games "Children of Asia"; international and 
Image slogans that "Kazakhstan is the Center of Eurasia".

reflect specifics of "Astana is the New World Wonder".

regional positioning

Territorial branding efficiency conditions price",

"Almaty is the Alps in Asia"
"Kokshetay is Switzerland for a fraction of

Kazakhstan has the first place among CIS states with the most favourable international image.

The most frequent positive words about Kazakhstan in global media-to win, champion, support, agreement, victory, sponsor, cooperation (Astana is the New World Wonder, 2014).

According to Newsweek magazine Kazakhstan has $61^{\text {st }}$ place in the list "The best countries of the world" (Influential regional state, 2014).

According to the report of the World Bank, Kazakhstan has moved four positions higher in rating "Doing Business 2011" and took $59^{\text {th }}$ place $\left(63^{\text {th }}\right.$ place according the calculation of 2010).

Kazakhstan took $105^{\text {th }}$ place in 178 possible in the index of corruption level, prepared by Transparency International in 2010. Kazakhstan and Moldova leads in this list from CIS countries with $105^{\text {th }}$ place. Armenia has $123^{\text {th }}$ place, Belorussia has $127^{\text {th }}$ place, Ukraine and Azerbaijan have $134^{\text {th }}$ place both, Russia has $154^{\text {th }}$ place (The world's best countries, 2014; Kazakhstan's positions in Global Ratings, 2014). Kazakhstan has leading positions of it is included in Top 50 in some other international ratings.
all-Russian cinema and theatrical projects; TV-projects "Finders" and projects of The First Channel "Mysteries of Yakutia" of Andrey I; all-Russian festival of mass-media "PR Days in Yakutia"; international rock festival "Tabyk"; International exhibition and trade-show of touristic routes and services "Sakha-travel"; separate project in the scope of development strategy of tourist industry in the Republic of Sakha (Yakutia) up to 2025, etc.

"The Land of Olonkho".

"Eastern Development Vector".

"Yakutia is a diamond in the crown of Russia".

"Yakutia is development driver of the Far Eastern District".

"The most rapidly developing region of the Far Eastern District of RF"

In 2009 Yakutia has class B (rating higher than average) in Russia Regions Rating by scale of living (multidimentional index, 2009).

In 2013 the Republic of Sakha (Yakutia) has medium positions in National Rating of Investment Climate Condition for RF subjects (Strategic Initiatives Bureau data).

The Republic of Sakha (Yakutia) has $70^{\text {th }}$ place of 83 by scale of living. 


\section{Discussion}

The government of the Republic of Kazakhstan supports purposeful activity aimed on forming and maintaining positive image of the country. Information and image policy includes several industry-specific programs and conceptions that represent strategically important directions of development of the state: industry, social and economic sphere, policy, legal structure, health care, education, etc. But according to some researchers (Country-specific PR, 2014) external image of Kazakhstan has ambiguous character because wide adoption of the country in political sphere does not guarantee its popularity among wide audience. Citizens of countries of different continents sometimes do not know not only geographical position of Kazakhstan but has no elementary associative array related to this country. "Economic wonder" i.e. The Astana city is not the brand that took its place in minds. State authority bodies are not always correlated in information content that is oriented on external audience.

Still it should be mentioned that pragmatic approach of Kazakhstan government has positive effect in countries interested for the country in political or economic sense. Russia, Kyrgyzstan, Belorussia, United Arab Emirates, China and the USA are among them. In CIS countries Kazakhstan has stable positive image as a former Soviet country that manage to get world recognition in short term (since 1991). Building of the new capital in this case is considered as demonstration of economic stability, power and investment attractiveness of the region. "Entering the list of world leaders is not an aim but an instrument that allows bringing Kazakhstan society to dramatically new level of development. It explains great investments made of making of new image of the country. Besides pure image aim, Kazakhstan has pragmatic aim. Sooner or later these investments will return via foreign policy capital" (Anafinova, 2014).

The Republic of Sakha (Yakutia) as it may be seen from some individual important in territorial branding data has rich potential for solving strategic tasks (Zalutskaya, 2013; Paninaandal, 2014; Impact factors and social communications development trends of the subjects if Asia-Pacific region, 2014). But one should note drawbacks that have negative impact on regional branding. It is first of all weakly developed infrastructure (roads, railway stations, communications, transport, hotels, cultural objects, public catering, public lavatories, consumer services, dwelling, the quality of provided goods, etc.). Modernization results will become obvious only in long-term perspective. Local community also has concerns about the state of multicultural heritage of people living in the territory of RS (Ya), degrading and loosing of historical and architectural objects of the region, complicated conditions for stimulation of business activity of citizens, problems of preserving unique nature and ecological safety of Yakutia that are related first of all with active sometimes hasty realization of industrial megaprojects.

\section{Conclusion}

The problems of social protection of population, development of favourable conditions for living and health protection of a man both in a city and in country-side remains pressing. For example there is still no defined strategy of social advertising, PR support of social projects and programs in the region. It is necessary to provide more examples of effective social partnership, appropriate support of these or those social initiatives. Number of actively operating social organizations that should intensify the process of forming of civil society should be increased. Domestic and foreign branding specialists note more and more frequently that the main principle of forming of powerful brand is the principle of humanization. Authorities that manage the process of effective promotion of a region are in charge for its realization. Branding success depends directly on the scale of living of a certain man on a certain territory. In present stage of Yakutia development this principle is just starting to realize in communication, image policy of the republic.

These drawbacks may be easily corrected. The process of branding positioning and forming of the image of the Republic of Sakha (Yakutia) in last three years became more active due to engagement of PR-specialists of Russian Federation and professionals of the AGT Communications Group (Moscow) (Tsoi, 2007; Zalutskaya, 2014; Today problems of regional social communications, 2013). Yakutia has all the necessary for professional and effective branding but under the condition of joining of all forces interested not in destroying existing achievements but enrich management of favourable image of Yakutia by new experience, new approaches and technologies.

\section{References}

Address of the President of the Republic of Kazakhstan N. Nazarbayev to People of Kazakhstan for 2006. (2006). Strategy of Kazakhstan entering the list of 50th most competitive countries of the world. Kazakhstan at the urge of the new advance in development. Retrieved September 23, 2014, from http://www.almaty.kz/page.php?page_id=950\&lang=1\&article_id=7325 
Address of the President of the Republic of Kazakhstan N. Nazarbayev to People of Kazakhstan for 2012. (2012). Strategy "Kazakhstan-2050"-New political course of matured state. Retrieved September, 23, 2014 from $\mathrm{http} / / /$ www.almaty.kz/page.php?page_id=950\&lang=1\&article_id=11654

Anafinova, M. (2014). Information and image program as an element of foreign policy of Kazakhstan. Retrieved September 23, 2014, from http://e-history.kz/ru/contents/view/1828

Antkholt, S. (2004). Branding: The way to global market. Moscwo: KUITs-OBRAZ.

Author. (2011). Conception of Image Policy of the Republic of Sakha (Yakutia) for 2012-2020. Yakutia Bulletin, 72.

Author. (2011). Social dimenions of image policy of a region. Moscow: Satellite.

Author. (2011, November 2). Astana is the new World Wonder. Retrieved September 23, 2014, from http://www.kazembassy.by/press/Astnovchudosveta.html

Author. (2014). Geobranding: Practical communication in promotion of territories: Educational and sceintific issue. Paris: L'Harmattan-IEERP.

Author. (n.d). Country-specific PR. Kazakhstan? Where it is? Retrieved September, 23, 2014 from http://www.ipr.kz/kipr/2/1/29

Author. (n.d). Influential regional state: Analysts has digitized image of Kazakhstan. Retrieved September 23, 2014, from http://www.astanaforum.kz/index.php?option=com_content\&view=article\&id= 121:2010-06-29-09-00-02\&catid=53:ii\&Itemid=123 (17.10.2011)

Author. (n.d). The world's best countries. Retrieved September 23, 2014, from http://www.thedailybeast.com/newsweek/2010/08/15/interactive-infographic-of-the-worlds-best-countries.h tml

Author. (n.d.). Kazakhstan's positions in global ratings. Retrieved September 23, 2014, from http://allbanks_kz_news/view_Pozitsii_Kazahstana_v-mirovih_reytingah

Bogachev, U. A. (2010). Challenges of development of modern Russian cities and problem of forming of their positive image. The People Friendship University of Russia Gerald, 2, 91-98.

Conception of Foreign Policy of the Republic of Kazakhstan for 2014-2020. (2014, January 21). Approved by the Order of the President of the Republic of Kazakhstan. Retrieved September 23, 2014, from http://kazembassy.ca/kazakhstan/koncepciya-vneshney-politiki-na-2014-2020

Dinnie, K. (2013). Branding of territories. Best global practices. In Mann Ivanov and Ferber (p. 13). Moscow.

Image policy of Russian Federation: Theory and practice of regions. (2012). All-Russian Scientific and Practical Conference. Ulan-Ude: ESSTU Publishing House.

Influence factors and development trends of social communications of subjects of Asia-Pacific region. (2014). International Scientific and Practical Conference, 2013. Irkutsk: ISEA.

Kotler, Ph., Aspl, C., Rein, I., \& Haider, D. (2005). Marketing places. St.-Petersburg.

Modern problems of regional social communications. (2013). International Scientific and Practical Conference "Influence factors and development trends of development of social communications of subjects of Asia-Pacific region". Yakutsk: S-VFU branch.

Panina S. V., Zalutskaya, S. U., \& Grigorieva, V. V. (2014). Image Making Potential of Higher Educational Establishment. Socio-Cultural Aspect, World Applied Sciences Journal, 29(7), 856-860.

Pavlova, L. N. (2012). The role of media in forming image of the Republic of Sakha (Yakutia). In Image-Modeling of a region in the context of modern development (pp. 227-236).Yakutsk: YakutskiKrai.

Pavlova, L. N. (2013). Information process as resource of society management in regional media. 52th Annual conference "MASS MEDIA IN THE MODERN WORLD. St. Petersburg Readings". Saint-Petersburg: St.-Petersburg State University Publishing House.

Samover, N. (2009). Brand for a map. Laboratory of advertising, marketing and public relations, 1, 37-39.

Tchernyshyova, A. M. (2014). Branding: handbook for Bachelors. Moscow: Urait.

Tchumikov, A. N., \& Bocharov, M. (2008). PR: theory and practice (p. 8). Moscow: Delo.

Tsoi, L. N. (2007). Organizational and managerial basics of improvement of competitiveness of a higher 
educational institution in regional education system. Irkutsk: Baikal University of Economy and Law Publishing House.

Vishnyakova, S. M. (1999). Professional education. Key concepts, terms, active vocabulary. Moscow: Scientific and methodical Center of Secondary Professional Education.

Zalutskaya, S. Y. (2013). Image policy of the Republic of Sakha (Yakutia): From the history of the problem. Promotion of the Republic of Sakha (Yakutia) in the context of general state strategy of development of Eastern Siberia and the Far Eastern District (pp. 9-16). Irkutsk: ISEA.

Zalutskaya, S. Y. (2014). Professional activity of a Bachelor in advertising and PR in the context of the theory of creative self-development of a personality. S-VFU Gerald, 11(1), 100-106.

\section{Copyrights}

Copyright for this article is retained by the author(s), with first publication rights granted to the journal.

This is an open-access article distributed under the terms and conditions of the Creative Commons Attribution license (http://creativecommons.org/licenses/by/3.0/). 